Corresponding Author: Kuslan

Sunandar; email:

kuslan15@gmail.com

Published: 7 February 2022

Publishing services provided by Knowledge E

(c) Kuslan Sunandar et al. This article is distributed under the terms of the Creative Commons Attribution License, which permits unrestricted use and redistribution provided that the original author and source are credited.

Selection and Peer-review under the responsibility of the IVCN Conference Committee.

\section{The Effectiveness of Rheumatic Exercise With Citronella Oil on Decreasing Pain Intensity in Pre-Elderly Experiencing Rheumatism}

\section{Kuslan Sunandar*, Henny Cahyaningsih and Tati Suheti}

Department of Nursing,Bandung Health Polytechnic, Bandung, Indonesia

\section{ORCID}

Kuslan Sunandar: https://orcid.org/0000-0001-6515-8261

Abstract. Rheumatic disease has a significant impact on individuals and society. This disease also affects the economy of the individual, society and country. The highest prevalence of joint disease in Indonesia based on diagnosis by health professionals or symptoms has been identified in East Nusa Tenggara (33\%), followed by West Sumatra (33\%), West Java (32\%), and Bali (30\%). The prevalence of joint disease in Bandung City has been reported as 27\%. Musculoskeletal system diseases and connective tissue problems (including rheumatism) are the second most common condition in women (69\%), after vascular system disease. A rheumatic exercise is a form of physical exercise that has a good effect on increasing the ability of joint muscles, which can improve fitness and increase endurance. If the muscles are frequently trained, the synovial fluid will increase, which can reduce the risk of injury and prevent knee pain in patients with knee rheumatism. Rheumatic exercises have a direct psychological impact, namely helping to give a relaxed feeling, reduce tension, and increase feelings of pleasure because during exercise the pituitary gland increases beta-endorphin levels. Increased concentrations of beta-endorphins in the blood and parasympathetic nerves reduce heart rate and pulse, causing the pain that causes joint stiffness to decrease. The purpose of this study was to determine the effectiveness of rhematic exercise with a modified combination of citronella oil to reduce pain intensity in the pre-elderly with rheumatism in Puskesmas Garuda Kota Bandung. This was a quasi-experimental study with a two group pre- and post-test design with a control. The average pain scale value before the intervention was 5.7 and the average pain scale after the intervention in the treatment group was 1.45. The rheumatic exercise intervention with a topical combination of citronella oil was more effective in reducing the intensity of rheumatic pain in the pre-elderly who had rheumatism in Garuda City Health Center, Bandung. The results may be useful for health workers to improve their performance in helping the community.

Keywords: Rheumatic exercise, pain intensity, pre-elderly

\section{Background}

Rheumatic disease has a major impact on individuals and on society. This disease also

G OPEN ACCESS 
begins to decline at the age of about 40 years, with a decline that accelerates after the age of 60 . lifestyle changes and use of the neuromuscular system are the main causes of loss of muscle strength. In general, there is a deterioration of the joint cartilage, mostly occurring in weight-bearing joints and bone formation on the joint surface. The components of the broken joint capsule and collagen present in the connective tissue increase progressively, which may cause inflammation, pain, decreased joint mobility, and deformity if no longer used. The most common inflammatory articular disease in the elderly is Rheumatoid Arthritis.

Based on data from Basic Health Research (2013), it shows that the prevalence trend of rheumatism in Indonesia in 2007-2013 at the age greater than 15 years was 30.3\% in 2007 , and decreased in 2013 , namely to $24.7 \%$. Meanwhile, data on rheumatoid sufferers in Indonesia based on gender tends to occur in women with a prevalence of 34\% [2]. The highest prevalence of joint disease based on diagnosis by health professionals or symptoms was in East Nusa Tenggara (33.1\%), followed by West Sumatra (33\%), West Java (32.1\%), and Bali (30\%) [3] [2].

Specific physical exercises aimed at affected muscles and joints. One of its implementations is rheumatic exercise, which involves stretching and strengthening the muscles that support [1] joints damaged or disturbed by rheumatism. When the joint supporting muscles strengthen, joint pain will decrease.

A rheumatic exercise is a form of physical exercise that has a good effect on increasing the ability of joint muscles which can provide fitness and increase endurance. If the muscles are frequently trained, the synovial fluid will increase. Synovial fluid functions as a lubricant in the joints, which means that the addition of synovial fluid to the joints can reduce the risk of injury and prevent knee pain in patients with knee rheumatism.

Active movements in rheumatic gymnastics aim to increase joint stability and strength of the muscles around the knee, namely Quadriceps, especially in the vastus medialis muscle because this movement is useful for reducing irritation that occurs on the surface of the patellar articular cartilage, maintaining and increasing active stability in the knee joint as well. can maintain nutrition in synovial for the better. With repetitive movements in rheumatic exercise, there will be an increase in the work of the muscles around the joints so as to accelerate blood flow and increase the metabolic process so that metabolic waste will be carried away by the blood flow out of the body through the excretory organs so that pain is reduced [4].

The problem in this study is the high incidence of Rheumatoid Arthritis in the elderly at the Garuda Health Center as many as 50 people. Pain causes elderly physical barriers or joint stiffness during activities, so researchers are interested in doing research on 
rheumatic exercise because the method of rheumatic exercise according to previous research can reduce pain intensity, easy and efficient, but very useful and efficacious for reducing knee pain and increasing range of motion in people with Rheumatoid Arthritis

Rheumatic exercise is one of the practical and effective methods of maintaining a healthy body. The results of Suhendriyo's research (2014) state that there is a significant effect in providing rheumatic exercise on reducing pain in patients with knee osteoarthritis in Karangasem Surakarta. The movements contained in rheumatic gymnastics are very effective, efficient, and logical movements because the series of movements are carried out regularly and organized for people with rheumatism [5]. In this study, rheumatic exercise was combined with the topical application of Citronella Oil. This is intended to increase the effectiveness of reducing rheumatic pain, because citronella oil contains main components including citronellal $32.58 \%$, geraniol $30.44 \%$, citronellol $14.31 \%$, which have anti-bacterial and anti-inflammatory properties.. Previous studies were conducted separately between rheumatic exercise intervention and the use of citronella oil to reduce rheumatic pain. So in this study carried out simultaneously or in combination. Topical citronella oil is done 5 minutes before exercising, given topical citronella oil first, this will help reduce pain. This will provide a sense of comfort to the pre-elderly when doing rheumatic exercises. Exercises movements will be carried out more perfectly, and of course this will give better results [6] [7].

\section{Methodology}

\subsection{Research Design}

The type of research used in this study is a quasi experimental design with two groups pre and post design with control, namely research conducted on two groups twice, namely before intervention (01) after intervention (02). This study was conducted to determine the effectiveness of rheumatic exercise with a topical combination of citronella oil on the intensity of rheumatic pain in pre-elderly in the Garuda's Community Health Center.

\subsection{Population and Sample}

The population in this study were all pre-elderly with rheumatism in the work area of the Garuda Health Center, Bandung City. The sample size was 40 people. 


\subsection{Method of Collecting Data}

The data collection procedures are as follows:

a. Identifying pre-elderly who meet the inclusion criteria is carried out during the Posbindu activities at RW 03 pos 1 and post 2

b. Perform randomisation to determine the intervention group and control group (double blind)

c. Pre-elderly who meet these criteria are given informed consent and are asked for consent to become respondents.

d. After obtaining the consent of the respondent, the measurement of pain intensity / pain scale is then carried out (pre test).

e. After identifying the pain intensity / pain scale, the rheumatism exercise intervention was carried out

f. (East Lombok Health Office) with a duration of 7 minutes with a topical combination of citronella oil (Citronella Oil obtained from pharmacies) twice a week for 4 weeks (a month) in the intervention group and rheumatic gymnastics intervention alone in the control group, giving lemongrass fragrance applied before rheumatic exercise started in the area that feels sick, for the control group lemongrass given after exercise, namely at the last meeting (8).

g. Exercise is carried out alternately for the intervention group and the control group because the room only contains about 20 to 25 people

h. Excercise was guided by 5 people, namely 2 cadres and 3 research team members

j. The media used are LCD and CDs for them to practice at home for those who have a $C D$ flayer for those who don't have it can join other people who have a $C D$ flayer.

i. After 4 weeks of intervention, measurement of pain intensity / scale is then carried out (post test)

1. Data Processing and Data Analysis

The data is processed using a computer. After the data is processed, then it is analyzed. The data is presented in tabular form. The principle of data analysis is to find out how the effectiveness of rheumatic exercise on reducing pain intensity in pre-elderly in the work area of Garuda Health Center, Bandung city. 
TABLE 1: Uji Mann Whitney result test pain scale post test rheumatic excercise in the Intervention group and control group

\begin{tabular}{l|l|l|l|l}
\hline Group & Mean Rank & Mann Whitney & Z score & P Value \\
$\begin{array}{l}\text { Intervention } \\
\text { Control }\end{array}$ & 11.8529 .15 & 27.0 & -4.834 & 0.000 \\
\hline
\end{tabular}

The analysis in this study used a two mean difference test. Two different tests mean to determine the effect of combined rheumatic exercise with topical citronella oil on rheumatic pain intensity in the elderly in the intervention and control groups. The two mean difference test can be done using the Dependent $t$ test (Paired $t$ test).

Furthermore, conducting an independent $t$ test (Pooled $t$ test) to determine the effectiveness of combined rheumatic exercise with topical citronella oil on reducing the intensity of rheumatic pain in the elderly in the intervention group with a control group that only performed rheumatic exercises.

Prior to further analysis, the data normality test was conducted first. If the normality test results show that the data is not normally distributed, then a non-parametric test is performed, namely the Wilcoxon signed rank test (paired t test equivalent test) to see the differences in each proportion. And the non-parametric Mann Withney test is equivalent to the pooled $t$ test. Hypothesis 0 is rejected if $p$ value $<\alpha .(\alpha=0.05)$. Data processing using a computer program.

\section{Results}

\section{Discussion}

\subsection{Pain scale before rheumatic exercise intervention}

The feeling of rheumatic pain causes a feeling of discomfort in sufferers of rheumatism. Everyone feels pain on a different or varying scale. This depends on the severity of the disease, the nature of the acute or chronic disease, and the individual's level of resistance or sensitivity to the pain that is felt. The disease is said to be acute if it is suffered for less than six months, after six months to one year it is said to be subacute, and if the disease is chronic, it is called chronic. People who have recently experienced pain tend to be more sensitive and say the pain is on a heavy or heavier scale, while people who have been in pain for years and are accustomed to rheumatic pain conditions will say the pain is normal. 
The results showed that, the average pain scale before the intervention group treatment was 5.7 and the mean pain scale of the control group was 6.25. The minimum pain scale before the intervention was 3 and the maximum was 9. Statistically, there was no difference in the pain scale before the intervention between the treatment and control groups. The pain scale in the two groups according to the results of statistical tests was comparable or there was no difference, this was in accordance with the requirements for intervention studies.

Rheumatic pain in the respondents of this study in the joints of the hands and feet. The joints of the feet that experience the most pain are the knee area. The knee joint withstands heavy loads every day during individual activities, especially when standing and walking. People who are overweight or obese in adulthood or middle age will experience rheumatism. The risk of knee joint pain in women is twice as much as in men[4]. In this study, $85 \%$ of respondents were female. All study respondents experienced joint pain with pain scales varying from moderate to severe controlled. This is also consistent with the clinical manifestations put forward by the American College of Rheumatology (ACR) Subcommittee, if it meets three of the following six things, namely: age $>50$ years, joint stiffness $<30$ minutes, crepitus, bone pain, bone enlargement [8]. This opinion is reinforced [8], who said that the main complaint that always appears in sufferers is joint pain. Joint pain occurs when the joints become obstructed during movement.

\subsection{Pain scale after rheumatic exercise intervention}

Rheumatic gymnastics intervention with a topical combination of citronella oil was carried out twice a week for four consecutive weeks carried out together at RW 03 Kelurahan Garuda, Bandung City.

The results showed that the mean pain scale after intervention in the treatment group was 1.45 and the mean pain scale in the control group was 4.3. The minimum pain scale after intervention is 0 and the maximum is 7 . Statistically, there is a difference in the pain scale after the intervention between the treatment and control groups. Joint pain in rheumatism sufferers is included in the category of somatic pain in which the pain receptors are located in muscles and bones and other body supports. The body has neuromodulators that can inhibit the transmission of pain impulses, one of which is beta-endorphins [8]. Endorphins play a role in reducing pain sensations by blocking the release of substance $p$ from sensory neurons so that the transmission of pain impulses in the spinal cord is inhibited and pain sensations are reduced [6]. The high level of 
beta-endorphins also has a direct psychological impact, which helps provide a feeling of relaxation, reduces tension, increases feelings of pleasure, makes a person more comfortable, and improves oxygen delivery to muscles [5]. According to Arthritis Care and Research, exercise can stimulate increased release of endorphins. Researchers found that exercise three times a week significantly improved arthritis patients' health, including OA [9] [10]. One of the simple and easy to do physical exercises is rheumatism [11]. Rheumatic exercises are exercises that focus on maintaining the maximum range of motion in the joints. This rheumatic exercise aims to reduce joint pain and maintain the physical health of people with rheumatism. Another advantage of rheumatic exercise is that bones become more flexible, muscles stay tight, improve blood circulation, keep blood fat levels normal, are not prone to injury, and the speed of reaction of body cells is better[12].The advantages of rheumatic exercise are not only active, repetitive, and easy to do movements. After doing the rheumatic exercise, the elderly look relaxed, comfortable, and show a smiling facial expression. According to research [11], exercise or gymnastics, including rheumatic exercise, has a direct psychological impact, which helps provide a relaxed feeling, reduces tension, and increases feelings of pleasure because during pituitary gland exercise increases production or increases beta endorphin levels.

\subsection{Difference in average pain scale before and after the rheumatic exercise intervention}

The results showed that, the average pain scale of the treatment group before the intervention was 5.7 with a minimum pain scale of 3 , a maximum of 8 . and the average pain scale after intervention was 1.45, with a minimum pain scale of 0 and a maximum of 6 . Statistically, there was a difference in the mean pain scale between the treatment groups before and after the intervention $(p=0.000)$. In this group, apart from doing rheumatic exercises, they were given topical or smeared citronella oil. Citronella Oil contains the main constituent components, namely citronellal with a peak area of $32.58 \%$, geraniol $30.44 \%, 14.31 \%$ citronellol which has anti-bacterial and antiimplamation properties [13]. The main content possessed is alcohol monoterpenes, namely linalool, geraniol and citronellol found in citronella oil which have activities as analgesics, calming and balancing, stimulants [7]. Citronella oil besides having medicinal properties mosquito repellent or mosquito repellent because of its fragrant properties, it turns out that it contains information and analgesics or as anti-inflammatory and antipain when applied to areas experiencing rheumatic disease. 
After the citronella oil sticks to the skin, absorption occurs. The absorption of aldehyde compounds and aldehyde esters that occurs when these compounds pass through the epidermis layer and lymph and blood channels, sweat glands, nerves, and enter the blood and enter every cell of the body to react, thereby causing anti-inflammatory and entering the blood. helps which can reduce the inflammatory process and reduce pain [14].

The results showed that the average pain scale of the control group before the intervention was 6.25 with a minimum pain scale of 4 , a maximum of 9 . and the average pain scale after intervention was 4.3, with a minimum pain scale of 3 and a maximum of 7. Statistically there was a difference in the pain scale before and after the intervention between the control groups $\mathrm{P}=0.000$.

The advantages of rheumatic exercise are not only active, repetitive, and easy to do movements. After doing the rheumatic exercise, the elderly look relaxed, comfortable, and show a smiling facial expression. According to research [15], exercise or gymnastics in this case including rheumatic exercise has a direct psychological impact, which helps provide a feeling of relaxation, reduces tension, and increases feelings of pleasure because when exercising the pituitary gland increases production or increases betaendorfin levels. This is supported [16], in addition to the production of beta-endorphins, exercise also increases nerve-channeling activity in the brain, namely an increase in parasympathetic neurotransmitters (norepinephrine, dopamine, and serotonin). An increase in the concentration of beta-endorphins in the blood and parasympathetic nerves decreases the heart rate and pulse, causing pain that gives rise to reduced joint stiffness.

\subsection{The effectiveness of rheumatic exercise with a combination of lemongrass oil in reducing the intensity of rheumatic pain.}

The statistical test proved that there was a difference in the average pain scale after the intervention between the treatment group and the control group $(P=0.000)$, so it could be concluded that rheumatic exercise with a topical combination of citronella oil was more effective in reducing the pain scale in rheumatoid sufferers.

The control group who only did rheumatic exercises after four weeks felt their joint pain reduced, although not until the pain went away. The treatment group who did rheumatic exercises with a topical combination of citronella oil felt their joint pain reduced and some even had a zero pain scale or the pain scale was 0 . So it seems 
clear that rheumatic exercise with a topical combination of citronella oil in this study can be more effective in reducing rheumatic pain [9].

There is an effect of rheumatic exercise on reducing pain scale. So that it can improve the ability to walk in the elderly. Rheumatic exercise is a type of light exercise that serves to overcome complaints that usually arise in rheumatic diseases, such as joint stiffness and pain, weakness and muscle tension. Rheumatic exercise is only one attempt to prevent and relieve the symptoms of rheumatism. Rheumatic exercise is one of the modalities to guide preventing and providing therapy for rheumatic symptoms or symptoms of osteoarthritis. Rheumatic exercise movements are intended to improve movement ability, function, muscle strength and endurance, aerobic capacity, balance, joint biomechanics and sense of joint position. This rheumatic exercise concentrates on joint movement while stretching and strengthening muscles, because these muscles help the joints to support the body [5]. In the rheumatic exercise intervention, it was combined with topical citronella oil, so that there was added value. Citronella oil contains aldehydes and esters which have properties that are easily absorbed by water. Absorption of these compounds takes place when these compounds pass through the epidermis layer of the skin and enter the lymphatics and blood, sweat glands, nerves, and enter the bloodstream and go to every cell of the body to react. , thus causing the effect of reducing pain, because it contains analgesic and anti-inflammatory [7].

\section{Conclusion}

The average pain scale before the treatment group intervention was 5.7 and the average pain scale of the control group was 6.25 . The mean pain scale after the intervention in the treatment group was 1.45 and the mean pain scale in the control group was 4.3. There was a difference in the average pain scale before and after rheumatic exercise ( $p$ $=0.000$ ). Intervention of rheumatic exercise with a topical combination of lemongrass oil is more effective in reducing the intensity of rheumatic pain in pre-elderly who have rheumatism in the work area of the Garuda Bandung City Health Center.

\section{Acknowledgments}

The implementing team of research activities would like to thank the Department of Nursing, Bandung Health Polytecnic, and Garuda Bandung City Health Center. 


\section{References}

[1] Sangha O. Epidemiology of rheumatic diseases. Rheumatology. 2000;39:3-12.

[2] KemenKes, R. I., and Indonesia KKR. Penelitian B, Pengembangan DAN, Pengantar K. Riset kesehatan dasar. Jakarta. 2013.

[3] Kemenkes RI. Riset kesehatan dasar 2013. Balitbangkes; 2013.

[4] Suhendriyo, S. (2014). Pengaruh Senam Rematik Terhadap Pengurangan Rasa Nyeri Pada Penderita Osteoartritis Lutut Di Karangasem Surakarta. Interest: Jurnal IImu Kesehatan, 3(1).

[5] Suwarni A, Murtutik L. Effektifitas senam rematik terhadap kemampuan berjalan dengan nyeri sendi untuk mencapai hidup yang sehat dan sejahtera pada lanjut usia. Jurnal IImu Keperawatan Indonesia (JIKI). 2017;10(1):1-12.

[6] Corwin. Buku saku patofisiologi. EGC. 2009

[7] Widowati I, Harnany AS, Amirudin Z, Pekalongan PK, Semarang PK. Pengaruh masase kaki dengan minyak sereh wangi terhadap penurunan tekanan darah hipertensi lansia di kota pekalongan. Pena Jurnal IImu Pengetahuan dan Teknologi. 2014.

[8] Wahyuningsih, S., Erwin, E., \& Nurchayati. Pengaruh Senam Rematik Terhadap Intensitas Nyeri Sendi Pada Penderita Osteoarthritis. 2020; 11(1), 16-24.

[9] Callahan, L. F., \& Ambrose, K. R Physical activity and osteoarthritis-considerations at the population and clinical level. Osteoarthritis and cartilage. 2015;23(1), 31-33.

[10] Kusumaningrum HP, Zainuri M, Endrawati H, Purbajanti ED. Characterization of citronella grass essential oil of Cymbopogon winterianus from Batang region, Indonesia. Journal of Physics: Conference Series. 2020;1524:12057.

[11] Ahmad AW, Heriyanto R. Business feasibility analysis of citronella and patchouli essential oil in Sawahlunto City. International Conference on Applied Science and Technology on Social Science (ICAST-SS 2020). Atlantis Press; 2021.

[12] Septiyanti M. Evaluation of nanoemulsion concentrate botanical fungicide from neem, citronella and eugenol oil using palm oil based surfactant. American Journal of Physics and Applications. 2019;7:14.

[13] Aisyah Y, Yunita D, Amanda A. Antimicrobial activity of patchouli (Pogostemon cablin benth) citronella (Cymbopogon nardus), and nutmeg (Myristica fragrans) essential oil and their mixtures against pathogenic and food spoilage microbes. IOP Conference Series: Earth and Environmental Science. 2021;667:12020. 
[14] Cooney, J. K., Law, R. J., Matschke, V., Lemmey, A. B., Moore, J. P., Ahmad, Y., ... \& Thom, J. M. Benefits of exercise in rheumatoid arthritis. Journal of aging research, 2011.

[15] Simanjuntak, E. E. Pengaruh Rutinitas Senam Rematik Terhadap Penurunan Tingkat Nyeri Pada Lansia Yang Menderita Rematik Di Panti Sosial Tresna Werdha Budi Luhur Kota Jambi Tahun 2018. Scientia Journal. 2018;7(2):54-60. 